\title{
The New Visibility of Religion in the Development Arena
}

Christian and Muslim elites' engagement with public policies in Africa

Mayke Kaag and Maud Saint-Lary

\section{OpenEdition}

\section{Journals}

Electronic version

URL: http://journals.openedition.org/apad/4075

DOI: $10.4000 /$ apad. 4075

ISSN: 1950-6929

\section{Publisher}

LIT Verlag

Printed version

Date of publication: 1 August 2011

\section{Electronic reference}

Mayke Kaag and Maud Saint-Lary, "The New Visibility of Religion in the Development Arena », Bulletin de I'APAD [Online], 33 | 2011, Online since 22 March 2012, connection on 07 September 2020. URL : http://journals.openedition.org/apad/4075 ; DOI : https://doi.org/10.4000/apad.4075

This text was automatically generated on 7 September 2020

Bulletin de l'APAD 


\title{
The New Visibility of Religion in the Development Arena
}

\author{
Christian and Muslim elites' engagement with public policies in Africa
}

Mayke Kaag and Maud Saint-Lary

\section{Introduction}

1 Contrary to the widespread tendency to relegate religion to the rank of reactionary forces, religious actors and ideas have always been vectors of social change and important in development initiatives in Africa - one only has to think of Catholic missions' or Islamic elites' engagement with education in colonial times (Cooper 2006; Brenner 2001). However, such engagements got increasingly unnoticed when modernization theories of development became dominant in the 1950s and 1960s. Only very recently has religion been rediscovered as a force of change (cf. Ter Haar \& Ellis 2006). This is due to both changes in thinking about development and changes that have occurred in African society, and this specifically in the religious domain.

\section{The 'religious turn' in Development Studies}

2 In 2004, the World Bank published a book tellingly entitled Mind, Heart, and Soul in the Fight Against Poverty. It emphasizes the need for collaboration between religious and development organizations in the fight against poverty and to further development; Christian and Islamic elites are considered inescapable allies in the execution of programmes in domains such as health, education, the environment and peacekeeping (Marshall \& Keough 2004). In the same vein, the Human Development Report 2007/2008 makes a plea to include religious values and partners in climate change policies. ${ }^{1}$

This explicit positive attention paid to religion in development cooperation circles over the last few years may come as a surprise, as religion and development seemed to be worlds apart for a long time. In the modernization paradigm that became dominant in Development Studies and practice from the 1950s and 1960s onwards, religion was not 
considered an issue. If it was treated as a subject at all, it was mainly seen as an impediment to development, or as something that would ultimately be overcome, as development would lift people out of ignorance. State-led and top-down development programmes left little room for participation of societal groups, including religious ones, in the policy process, and for development scholars and policy makers to consider initiatives beyond the state.

4 The situation changed gradually in the 1980s as structural adjustment policies and less involvement by the State in sectors such as education, healthcare and social services led to a diversification of development actors (NGOs, associations), that attempted to fill in the gaps left by the State. In the meantime, strict macro-economic approaches to development were replaced or in many cases supplemented by more holistic views of 'human development' (Sen 1997, 2000) that go beyond a purely economic approach by including social, psychical and cultural factors too. 'Livelihoods' approaches (Chambers \& Conway 1992; Carney 1998) with their emphasis on people's own strengths and development strategies became influential in tandem with participatory and bottom-up policies. This pattern fitted nicely with the neoliberal paradigm and its focus on privatization and citizens' own responsibilities (Kaag et al. 2004).

However while these new approaches claimed to be holistic and people-centered, they were still predominantly 'lay' in character, with an accent on the (socio-) economic aspects of human development. It was only towards the turn of the century that religion and culture became more important in the analysis. A revealing example is the theory of the 'clash of civilizations' (Huntington 1996) that has become influential in the understanding of geo-political conflicts. Interestingly, this basic recognition that culture (including religion) matters in the global era, which has been negatively interpreted by Huntington, has inspired others in Development Studies, as well as in development practice, to see religion as a force in development, as is shown by the title of the World Bank report cited above.

In the meantime, an entire corpus of empirical work has developed that rejects visions that are too simplistic and generalizing and shows the crucial role of religious institutions in the functioning of contemporary African societies and their economic development (Copans 1989; Fall 2011). In the case of Senegal, the accent is on Islam as a popular political counterculture (Coulon 1983; Seck 2010) but it has also been questioned whether Islam should be seen as a means by which political and religious elites are retaining power (Gueye \& Seck 2011). In general, the religious sphere is considered to provide social protection on the basis of charitative principles (Vuarin 1990; Weiss 2002) while empirical studies have also demonstrated that religion can be seen as a force of change (Brenner 1993) in development. A specific and growing corpus of literature concerns faith-based organizations (Bornstein 2003). These organizations may have diverse objectives ranging from evangelization in combination with the promotion of local economies (Yaro 1998) to fighting HIV/AIDS (Delaunay et al. 1998) but are generally considered to be more effective because of a supposed cultural proximity to their target groups (Benthall 2007).

7 Around the turn of the $21^{\text {st }}$ century, anthropological approaches linking religion and public life (Sounaye 2007) have multiplied. These show the strong societal engagements of religious actors (Kaag 2011), and religiously inspired forms of citizenship implicating religious militants in the urban public sphere (Gomez-Perez \& Leblanc 2007). Social juniors, like youngsters and women, access new modes of public expression 
(Masquelier 2009; Soares 2009). Recent anthropological works often explicitly highlight the religious issues involved in politics, policies and the public sphere but it should be acknowledged that 'anthropological' voices have to date been marginal in mainstream development thinking. ${ }^{2}$

\section{Religious revival in action}

8 Parallel to the changes in thinking about development described above, a number of changes in society have contributed to the renewed visibility of religion in the development arena. These concern the phenomenon of religious 'revival'. While the religious factor has always been important in Africa, new dynamics have given these religious elements a more openly public dimension over the last few decades. Globalization and technological progress (Saint-Lary, Samson \& Amiotte-Suchet 2011), which have contributed to a globalization of religious discourses, have helped these changes to occur. Pentecostal churches and Islamic reformist movements are using new technological means to appropriate the mass media and, in doing so, are reviving rivalries with other actors. Religious reformism, be it Islamic, Catholic or Protestant, inspires religious leaders to diffuse strong norms, rectify cult practices and instill social and moral values.

The phenomenon of 'revival', which can be observed across Africa since the 1990s, is the result of several factors. Since the $1970 \mathrm{~s}^{3}$, the contexts of the Kippur war, the oil boom and the severe droughts in sub-Saharan Africa have contributed to the reinforcement of African -Arab relationships (Triaud 2007). In addition, the Islamic Revolution in Iran (1979) gave a new face and new international visibility to political Islam and created new vigor among certain sectors of Muslims in Sub-Saharan Africa (Triaud 2007: 10). The new connections between the Arab world and Sub-Saharan Africa (Loimeijer 2005; Bunza 2005; Miran 2006; Kaag 2007) and the subsequent bilateral cooperation have resulted in substantive flows of development aid (Cissé 1994). The Pentecostal churches have not lagged far behind, with the Universal Church of the Kingdom of God (UCKG) being a clear testimony to this. The UCKG is well known for its capacity to capture the media and mobilize its faithful followers exponentially (Corten, Dozon \& Oro 2003).

10 Sub-Saharan Africa is thus currently observing an expansion of its 'religious public space' (Holder 2009) where proselytizing strategies are being elaborated but action plans are also being introduced to improve societal relations. Religious elites today are frequently investing in struggles with religious and socio-political objectives. The gist of the discourses and public actions testify to this. The majority of the contributions in this issue show how religious organizations are participating in the construction of public structures for health and education, just as they are also installing forms of solidarity to face calamities and cope with economic crises when necessary.

\section{Religious elites in the development arena}

11 The new visibility of religious actors and ideas in 'development', as elaborated on in the previous sections, is an interesting phenomenon that deserves more in-depth attention. However, we think we should not restrict ourselves to the currently fashionable Faith-Based NGOs (FBOs) (Bornstein 2003; Hofer 2003) but discuss the topic 
from a historicizing angle and take a broad societal perspective. We therefore propose focusing on religious elites, be they individuals, leaders and/or spokesmen of official organizations, or of informal groups. This allows for to the inclusion of historical examples. In addition, we have not restricted ourselves to local dynamics but have also included a transnational perspective. The articles show how local religious elites may be brokers between international organizations and local target groups, such as the Senegalese Islamic association Jamra (Gomez-Perez this volume). Their activities may be financed by international financial streams such as zakat from the Gulf countries or by the mobilization of resources by local believers.

In addition, the polysemic character of the term 'elites' should not lead to confusion: religious elites may not only include 'official' holders of religious knowledge disposing of theological certificates, but also preachers formed 'on the spot' but not less active in public life. Religious elites share the characteristic that they enjoy an authority among the believers. The latter may take the religious elites' knowledge, relational capital and/or charisma as the main pillars of legitimacy, but the result is always the same: the religious elites are considered to be capable of acting in the public domain and transferring messages that have a strong societal bearing. The contributions to this issue reflect on the positions, strategies and perceptions of these religious elites who are engaged in 'development' in one way or another, and this in different West African contexts, (Niger, Burkina Faso, Senegal, and Nigeria), and in different periods of time (from pre-colonial to very recent years).

Nasir Mohammed Baba analyses the role of the ulama (Islamic clerics) in the promotion of Islamic education in northern Nigeria from the pre-colonial to the post-colonial era. $\mathrm{He}$ describes the complex historical pattern of co-operation, competition and avoidance that characterize the relationship between Ulama and the state in the education arena, concluding that the Nigerian state is currently acknowledging the importance of good-quality basic education for all but has failed to constructively engage with and regulate the participation of Islamic religious elites and groups in the provision of education. On the contrary, Baba argues, the growing sense of isolation felt in Islamic schools has enabled religious elites to consolidate their control over curricula content and management structures in ways that may not always contribute to educational development and national unity.

Abdoulaye Sounaye's contribution focuses on the expansion of Islamic development initiatives in Niger in the last decade. He particularly looks at how the notion of doing development the Islamic way has emerged in the public sphere and mobilized a diversity of Muslim actors. Comparing the views and activities of the international Islamic NGO AMA (Agence des Musulmans d'Afrique) and local Islamic development entrepreneurs, Sounaye analyses what doing development in the Islamic way means for them and how this affects their activities and relationships with the target groups.

Katrin Langewiesche deals with the question of interreligious dialogue in Burkina Faso, a topical issue that has hardly received any attention to date in the social sciences. She considers the partnerships that have been forged over the last ten years in the domain of healthcare between religious organizations and the state in Burkina Faso. She thus shows that religious elites are increasingly involved in transmitting information on public health issues. In addition, interreligious dialogue in the Burkinabe context is becoming a way for organizations to position themselves in the development arena visà-vis the state and international donors. 

two Islamic NGOs in Senegal in their fight against HIV/AIDS. She discusses how these organizations have established themselves in a context where the State is retreating and international aid organizations are becoming more involved. The Senegalese Islamic NGOs on the one hand have responded to this international call and are successfully engaging religious leaders in the fight against AIDS but at the same time developing their own approaches inspired and legitimized by the Quran and the Hadiths, which do not always comply with the approaches and objectives of the State and the international donor community.

Despite the variety of actors and contexts covered in this issue, some common themes emerge. These centre around questions of collaboration and rivalry with other development actors, such as the state and non-religious organizations; the importance of legitimizing discourses, be it towards international partners or local target groups; the ways in which they construct their tasks and roles in response to societal needs and opportunities; and the effects of developmental engagement of religious elites for the outlook of society and the State.

\section{Collaboration and rivalry}

Religious actors and others involved in 'development', such as the State, secular international organizations and secular local NGOs, maintain links that may go from frank collaboration to more or less open rivalry.

Sometimes, the religious may position itself as a real rival by openly criticizing the actions of state agencies and/or secular NGOs that are considered immoral or in conflict with religious rules. Conflicts over norms can thus cause a test of strength between religious and secular institutions. Muriel Gomez-Perez shows how Islamic elites consider the mass distribution of condoms as an invitation to immoral behavior and, just like the Pope, firmly reject institutions that collaborate in this kind of activity.

Nevertheless, analysis of development arenas also shows relationships between religious actors and others that are based on interdependence and collaboration, be it formal or informal, in public discourse and/or action. The influence of the religious elites is, for instance, largely mobilized for the legitimization of sensitizing programs in different domains, such as in the fight against HIV/AIDS (contributions by Katrin Langewiesche and Muriel Gomez-Perez this issue). A number of religious actors engaged in a fight of pan-African and global dimensions, consider the ideals of 'development', such as family planning, vaccinations, the struggle against poverty, as issues concerning both Muslims and Christians, while the economic conjuncture is an additional mobilizing factor. The organizations work to show their legitimacy in the development context. Katrin Langewiesche demonstrates, in relation to the interreligious dialogue in Burkina Faso, that this sometimes leads to the construction of a 'religiously correct' discourse in the face of international organizations. In any case, it appears that, among many international organizations, it has been realized that their ideal of 'participation' cannot be reached except with the support of influential, charismatic persons. Among these one has to count religious leaders. As a result, a growing number of religious intermediaries are emerging in the development sector, who present themselves as 'translators' of canonic texts and show the target groups that certain actions are well founded from a religious perspective. As is shown by

Bulletin de I'APAD, 33 | 2011 
Abdoulaye Sounaye, these actors accumulate a double competency register based on the one hand on their knowledge of the official language and their western-style education, and on the other hand on their knowledge of Islam which permits them to argue theologically. They can, for instance, sensitize the population to participate in vaccination campaigns by citing the right Hadiths.

However, as the religious is often plural, co-operation of some with the state may incite the dissatisfaction of others who accuse them of being corrupted. This raises the question of the degree and effect of religious segmentation in the case of communal management of societal questions together with government agencies. Considering the dynamics of rivalry within the Islamic sphere, certain actors have seen it as their mission to counter the anti-western discourse of some of their fellow-believers which, in their eyes, is counterproductive if one wants to contribute to 'development'. Within one religion, the readings of religious texts may differ and lead to different visions of the desired and necessary sensitizing actions.

In a more general sense, religious discourses are to an important degree based on salvation rhetoric, encouraging believers to work in the Here and Now and think of the Hereafter. They construct a moral economy of salvation in which development actions take shape.

\section{The religious in the construction of the 'social state'}

The dynamics described above present themselves in a context of crisis, both financial and economic, having brought the continent to a situation of prolonged poverty for both urban and rural populations. The hopes raised in the 1990s by democratization policies have today given way to a general feeling of deception. Observations are indeed not that positive: the failure and privatization of the State, repeated cereal crises (2004-2005), electricity cuts, poor functioning of health provision systems, uncontrolled urbanization, and revolts against the high costs of living. In the face of the so-called crisis of the extended family and the tensions on community solidarity, religious solidarity networks are filling the gap and offering support in a context of precariousness. They are substitute for the State in its social and protective function and appropriating the public policy domain related to gender, the fight against poverty, education and health. It should be noted that the budgets of religious organizations, both Christian and Islamic, are also progressively permitting them to play such a role.

These networks have been enjoying financial support from abroad for many years. On the Islamic side, petrodollars have been financing development activities and sponsoring NGOs, while on the Christian side, the funds for African Pentecostal networks are coming from the US and have resulted in the these churches being viewed as 'American'. In their more recent and fundamentalist versions, the neoPentecostals, like the Universal Church of the Kingdom of God, have been receiving funds also from Brazil. These financial flows have contributed to the structuring of transnational hierarchies and a strong dependency on external support.

However, local religious leaders have been successful in mobilizing their followings and gaining relative economic autonomy beyond their external funding. The religious sphere is benefitting from an economic basis fed by the believers themselves who collect money, even sometimes contributing substantial sums to their religious 
institutions. The economic power of the religious sphere is not a new phenomenon in African societies, but is now taking on particular forms and dimensions. Whether one thinks of zakat, the Maecenas-ship of big entrepreneurs (Cisse 2009), ostentatious gifts to pastors (Furtado, Laurent \& Plaideau 2009), benedictions, the 'prayer economy' (Soares 1996, 2005; Last 1988) with gifts of cash during celebrations like the Mawlud (Saint-Lary 2006) or whether one thinks of adherence fees to associations or religious marketing (Soares 2007) (knickknacks, posters, cassettes, books), the religious market can be seen to be inserting itself between the market economy and the moral economy (Triaud \& Villalon 2009). This allows the religious sphere to exist and play a role in the development arena, with substantial room for maneuver regarding objectives. The initiatives of religious actors are neither exclusively financed by secular institutions in need of religious caution or by a foreign religious hierarchy. They are partly financing themselves, and thus becoming increasingly autonomous in the development domain. The religious elites are thus participating fully, with their own means, in the functioning of African states and societies.

All of these phenomena, which seem to indicate the emergence of a religious welfare state - or what Maria Das Dores Campos Machado (2003) qualifies as 'welfare organization' - raise the question of secularity. In effect, this participation of the religious sphere in public policies shows how secularization does not, as in Europe, lead to a process of declining social influence of religion (Williame 2006). The existence of a postmodern religious fact, or to adopt the expression of Hassane Souley (2009) of a postmodern Islam, does not preclude the fact that the concerned States are secular, with a specific understanding of this principle. The three pillars of secularity, namely the equal treatment of all religions, freedom of religion, and the institutional separation of the religious and the political domain (Baubérot 2007) are articulated in a specific manner in West Africa. In addition, considering the role of religious elites in development arenas means taking into account the possible existence of secularities 'in an African way', where the religious participates in the construction and functioning of African states, without necessarily conquering them. What these religious elites in 'development' want to conquer is less the State in its regal sense (justice, police, etc) than the state in its social dimension.

\section{BIBLIOGRAPHY}

BAUBÉROT, J., 2007. Histoire de la laïcité en France, Paris, PUF (Que sais-je ?), $4^{\mathrm{e}}$ édition.

BENTHALL, J., 2007. Islamic Charities in Southern Mali Today. Islam et sociétés au sud du Sahara 1, $2007: 165-174$.

BORNSTEIN, E., 2003. The Spirit of Development: Protestant NGOs, Morality, and Economics in Zimbabwe, London New York, Routledge.

BRENNER, L., 1993. Muslim Identity and Social Change in Sub-Saharan Africa. London, Hurst. 
BRENNER, L., 2001. Controlling Knowledge. Religion, Power and Schooling in a West-African Muslim Society, Bloomington, Indiana University Press.

BUNZA, MUKHTAR UMAR, 2005. 'The Iranian model of political Islamic movement in Nigeria (1979-2002), in: M. Gomez-Perez (ed.), L’islam politique au Sud du Sahara. Identités, discours et enjeux, Paris, Karthala: 227-241.

CARNEY, D., (ed.) 1998. Sustainable Rural Livelihoods: What Contribution Can We indent Make? London, DFID.

CHAMBERS, R. \& G.R. CONWAY 1992. Sustainable Rural Livelihoods: Practical Concepts for the $21^{\text {st }}$ Century, Sussex, IDS.

CISSÉ, I., 2009. 'Le wahhabisme au Burkina Faso: Dynamique interne d'un mouvement islamique réformiste', Cahiers du CERLESHS, XXIV,33,pp. 1-33.

CISSÉ, I., 1994. 'Islam et État au Burkina Faso: De 1960 à 1990’, PhD Thesis (Triaud dir.), Université d'Aix, 2 Vol.

COOPER, B., 2006. Evangelical Christians in the Muslim Sahel, Bloomington, Indiana University Press. COPANS, J., 1989. Les Marabouts de l'arachide : la confrérie mouride et les paysans du Sénégal, Paris , le Sycomore, « Les Hommes et leurs signes ».

COULON, C., 1983. Les musulmans et le pouvoir en Afrique noire, Paris, Karthala.

CORTEN, A., DOZON, J-P. \& ORO, A. P., 2003. Les nouveaux conquérants de la foi. L'Eglise Universelle du Royaume de Dieu (Brésil), Paris, Karthala.

DELAUNAY, K., 1998. « Des ONG et des associations: concurrences et dépendances sur un "marché du Sida" emergent. Cas ivoirien et sénégalais ", in Deler, J-P., Fauré, Y.A., Piveteau, A. et Roca, P.J. (dir.), ONG et développement. Société, économie, politique, Paris, Karthala : 115-141.

DOZON, J-P., 2009. « Remémoration coloniale et actualisation politique dans la confrérie mouride », L'Islam, nouvel espace public en Afrique, Paris, Karthala : 225-236.

FALL, A.S., 2011. « Les usages des liens confrériques dans l'économie sénégalaise. », in Kaag, M. (dir), Islam et engagements au Sénégal. Leiden, African Studies Centre.

FURTADO, C., LAURENT, P-J \& PLAIDEAU, C., 2009. « L'Eglise Universelle du Royaume de Dieu du Cap-Vert. Croissance urbaine, pauvreté et mouvement néo-pentecôtiste ", Bulletin de l'APAD, $\mathrm{n}^{\circ}$ 29-30:9-25.

GOMEZ-PEREZ, M., 2005. L'islam politique au Sud du Sahara. Identités, discours et enjeux, Paris, Karthala.

GOMEZ-PEREZ, M. \& LEBLANC, M-N, 2007. «Jeunes musulmans et citoyenneté culturelle : retour sur des expériences de recherche en Afrique de l'Ouest francophone ", Sociologie et sociétés, vol 39 (2) : 39-59.

GUEYE, C, \& A. SECK, 2011. «Islam et politique au Sénégal : logique d'articulation et de coproduction » inKaag, M. (dir), 2011, Islam et engagements au Sénégal. Leiden, African Studies Centre

HASSANE, S., 2009. "Société civile islamique et nouveaux espaces publics au Niger. Esquisse sur l'islam postmoderne et les pratiques religieuses "globales" en Afrique, in Holder (dir.), L'Islam, nouvel espace public en Afrique, Paris, Karthala : 101-125.

HODGKIN, E., 1998. « Islamism and Islamic Research in Africa », in Kane et Triaud (éds), Islam et islamismes au sud du Sahara, Paris, Karthala : 197-262. 
HOLDER, G., 2009. L'Islam, nouvel espace public en Afrique, Paris, Karthala.

HOFER, K., 2003, The Role of Evangelical NGOs in International Development: A Comparative Case Study of Kenya and Uganda, Afrika Spectrum 38(3): 373-398.

HUNTINGTON, S., 1996, The Clash of Civilizations and the Remaking of World Order. New York, Simon \& Schuster.

KAAG, M. et al2004, 'Ways forward in livelihood research.' In: Kalb, D., W. Pansters \& H. Siebers, Globalization \& Development. Themes and Concepts in Current Research, Dordrecht/Boston/London, Kluwer Academic Publishers.

KAAG, M., 2007, 'Aid, Umma and Politics: Transnational Islamic NGOs in Chad', in: R. Otayek \& B. Soares (eds), Muslim Politics in Africa, New York, Palgrave Macmillan: 85-102.

KAAG, M. (éd), 2011, Islam et engagements au Sénégal. Leiden : African Studies Centre.

Krznaric, R., 2007, For God's Sake, Do something! How Religions Can find Unexpected Unity Around Climate Change. Human Development Report 2007/2008 Occasional Paper, Washington, Human Development Report Office.

LAST, M.,1988, "Charisma and Medicine in Northern Nigeria", In : Cruise O’Brien, D. B. et C. Coulon eds., Charisma and Brotherhood in African Islam. Oxford, Clarendon Press : 183-204.

LOIMEIER, R., 2005, « De la dynamique locale des réformismes musulmans. Etudes biographiques (Sénégal, Nigeria, Afrique de l'Est) », in Gomez-Perez (dir.) L'islam politique au Sud du Sahara. Identités, discours et enjeux, Paris, Karthala.

MACHADO, M., 2003, “L'IURD : une “organisateur providence”, in Corten, Dozon et Oro (dir.), Les nouveaux conquérants de la foi. L'Eglise Universelle du Royaume de Dieu (Brésil), Paris, Karthala : 245-256.

MARSHALL, K. et KEOUGH, L., 2004, Mind, Heart, and Soul in the Fight against Poverty. Washington DC, World Bank.

MASQUELIER, A., 2009, Women and Islamic Revival in a West African Town, Bloomington, Indiana University Press.

MIRAN, M., 2006, Islam, histoire et modernité en Côte d'Ivoire, Paris, Karthala.

OLIVIER DE SARDAN, J-P., 2000, « Dramatique déliquescence des États en Afrique », Le Monde diplomatique, février-2000.

OTAYEK, R., 1993, « Une relecture islamique du projet révolutionnaire de Thomas Sankara », in : Bayart, J.-F. (éd.), Religion et modernité en Afrique Noire : 101-127.

SAINT-LARY, M., 2006, Les chefs peuls du Yatenga à l'épreuve du changement (Burkina Faso), Thèse, EHESS, Marseille.

SAINT-LARY, M., SAMSON, F. \& AMIOTTE-SUCHET, L. 2011. Les outils d'un islam en mutation. Réislamisation et moralisation au Sud du Sahara, Ethnographiques.org.

SECK, A., 2010. La question musulmane au Sénégal. Essai d'anthropologie d'une nouvelle modernité, Paris, Karthala.

Sen, A., 1997. Editorial: Human Capital and Human Capability, World Development, 25(12): 1959-1961.

SEN, A., 2000. Human Development and Economic Sustainability, World Development, 28 (12): 2029-2049. 
SOARES, B. F., 1996. "The prayer economy in a Malian town", Paris, Cahiers d'Etudes Africaines, 36 (4): 739-753.

SOARES, B. F., 2005. Islam and the Prayer Economy. History and Authority in a Malian Town, Edinburgh, Edinburgh University Press.

SOARES, B. F., 2007. "Saint and Sufi in contemporary Mali", In M.van Bruinessen and J.D. Howell (eds.), Sufism and the 'modern' in Islam, London I.B. Tauris : 76-91.

SOARES, B.F., 2009. “An Islamic social movement in Contemporary West-Africa: NASFAT of Nigeria”, In: S. Ellis and I.van Kessel, Movers and Shakers: Social Movements in Africa, Leiden, Brill: 178-196.

SOUNAYE, A, 2007. “Instrumentalizing the Qur'an in Niger's Public Life”, Journal for Islamic Studies, vol.27: 211-239.

TER HAAR, G. \& S. ELLIS, 2006. The Role of Religion in Development: Towards a New Relationship between the European Union and Africa, The European Journal of Development Research, vol. 18, no. 3, September 2006: 351-367.

TRIAUD, J.-L., 2007. « L'islam au sud du Sahara : pistes de réflexion », In Souley, Moyet, Seck et Zakari, Islam sociétés et politique en Afrique Subsaharienne. Les exemples du Sénégal, du Niger et du Nigéria, Paris, Les Indes savantes.

TRIAUD, J.-L., \& VILLALON, L., 2009. « L'islam subsaharien entre économie morale et économie de marché : contraintes du local et ressources du global », Afrique contemporaine (3), n 231 : 23-42.

UNITED NATIONS DEVELOPMENT PROGRAMME, 2007. Human Development Report 2007/2008 Fighting Climate Change. Human solidarity in a divided world. New York, Palgrave Macmillan.

VUARIN, ROBERT, 1990. « L'enjeu de la misère pour l'islam sénégalais », Tiers-Monde, tome 31, $\mathrm{n}^{\circ} 123: 601-621$.

WEISS, H., (ed) 2002. Social Welfare in Muslim Societies in Africa, Uppsala, Nordiska Afrikainstitutet. WILLAIME, J-P., 2006. « La sécularisation : une exception européenne ? Retour sur un concept et sa discussion en sociologie des religions », Revue Française de Sociologie, 47-4 : 755-783.

YARO, G. J., 1998. « De l'évangélisation au développement local. Spécificité des ONG d'inspiration protestante au Burkina Faso », in Deler, Fauré, Piveteau et Roca (dir.), ONG et développement. Société, économie, politique, Paris, Karthala : 143-155.

\section{NOTES}

1. See, in particular, an occasional paper accompanying the report, entitled "For God's Sake, Do Something! How Religions Can find Unexpected Unity Around Climate Change" (Krznaric 2007).

2. Interestingly, the 'discovery' of religion by development theorists and practitioners, seems to imply a (renewed) appreciation of anthropology as a discipline in these circles.

3. Jean-Louis Triaud (2007) indicates two other periods that have been important for the expansion of Islam in Sub Saharan Africa, namely the $18^{\text {th }}$ century, the era of the Fulbe jihad, and the colonial period. 